\title{
Carboxypeptidase A1
}

National Cancer Institute

\section{Source}

National Cancer Institute. Carboxypeptidase A1. NCI Thesaurus. Code C113584.

Carboxypeptidase A1 (419 aa, $\sim 47 \mathrm{kDa}$ ) is encoded by the human CPA1 gene. This protein plays a role in enzyme metabolism. 